\title{
Stages of Pregnancy of the Bank Vole
}

\author{
Wacław OŻDŻEŃSKI ${ }^{1} \&$ Ewa T. MYSTKOWSKA ${ }^{2}$
}

\begin{abstract}
Ożdżeński W. \& Mystkowska E. T., 1976: Stages of pregnancy of the bank vole. Acta theriol., 21, 20: 279-286 [With 2 Tables \& Plates IV-VI]

A sequence of changes occurring in the reproductive organs in the course of pregnancy and changes in the weight, length and morphology of foetuses of the bank vole, Clethrionomys glareolus (S ch reber, 1780 ) in the period between 9th day of pregnancy and parturition are described. Weight and crown - rump lenght of the foetus represent suitable parameters to establish the stage of pregnancy between 10 and 15 days. Between 9 and 16 days of development certain morphological features can be used to determine the age of the foetus.

[1 ${ }^{1}$ Dept. Embryol., Zool. Inst., Univ. Warsaw, Krakowskie Przedmieście 26/28, 00-927 Warszawa, and 2 Lab. Exp. Embryol., Inst. Obst. Gynaec. Med. Acad., Karowa 2, 00-315 Warszawa]
\end{abstract}

\section{INTRODUCTION}

In the course of field investigations it is often necessary to establish the stage of pregnancy in trapped females since the moment of fertilization is not know. This is only possible on the basis of the appearence of sexual organs and on the size and morphology of foetuses. Knowledge of the course and rate of embryonic development may also prove useful in investigations on animals bred in captivity.

The information presented makes it possible to establish the existance of pregnancy in the bank vole by examination of reproductive organs and to determine the stage of gestation between the 9th day and birth by examination of the foetuses. The description of the embryonic development from the moment of implantation until the 9th day of pregnancy is the subject of separate publication $(\mathrm{O} \dot{z} \mathrm{~d} \dot{z} \mathrm{en} s \mathrm{~s}$ i \& Mystkowska, 1976).

\section{MATERIAL AND METHODS}

In these investigations 85 female bank voles from the stock maintained in the Mammals Research Institute of the Polish Academy of Sciences in Białowieża (B u chalczy k, 1970) were used. The females were examined daily between 8.30 and 11.00 a.m. for the presence of a vaginal plug which indicated copulation. The day a plug was discovered was designated as the first day of pregnancy. 
The mated females were killed at various stages of pregnancy for examination. Altogether 120 foetuses from 24 females were collected and examined. The size and weight of non-fixed foetuses was measured from the 10 th day of gestation. Eight pregnant females were left until parturition to establish the length of gestation. Vaginal smears of pregnant and non-pregnant females were made to establish a method of detecting pregnancy and the stage of gestation in living animals.

Only non-lactating females were used in order to eliminate the phenomenon of prolongation of pregnancy due to delayed implantation in lactating animals (Brambell \& Rowlands, 1936; Tupikova, 1964).

\section{RESULTS}

\section{Vaginal Smears}

Permanent oestrus was observed as a rule in non-pregnant females kept in laboratory. This is in agreement with earlier observations indicating that in this species provoked ovulation occurs (C la rke et al., 1970). Vaginal smears made between the $3 \mathrm{rd}$ and 10 th day of pregnancy showed the presence of mucous, resembling dioestrus in the mouse or rat. This type of smear persists until parturition. Between 11 th and 15th day of pregnancy the so called vaginal bleeding occurs for 1 to 3 days. This is a mucous excretion, brown in colour due to the presence of haemolysed blood. In the event that implantation did not occur (in our material $70 \%$ of all mated females) oestrus was maintained. 4 to 8 days after parturition oestrus appeared again.

Among the described phenomena only the vaginal bleeding can be practically utilized for detecting pregnancy.

\section{Ovaries}

Corpora lutea reach considerable dimensions in the bank vole. They have the appearance of cream-pink bulbs attached to the ovary and are already easily visible with the naked eye on the second day after mating. The presence of a corpus luteum is a good indicator of ovulation but not necessarily of pregnancy since it may persist for a few days even in those females in which implantation did not occur.

\section{Uterus}

Swelling of the uterus at the implantation sites can be observed starting from the evening on the 5th day of pregnancy. These swellings, small on the 6th day (Plate IV, Fig. 1) quickly increase in size and on the 7 th day are round in shape (Plate IV, Fig. 2). This situation persists until the 12th or 13th day of pregnancy (Plate IV, Fig. 3, 4), when the foetus and placenta become visible through the uterine wall, probably due to 
atrophy of covering decidua and decrease in the thickness of myometrium which undergoes considerable stretching. Rapid growth of foetuses results in a change of the shape of implantation swellings which become elongated or oval on the 13-14th day (Plate IV, Figs. 5, 6).

\section{Size and Weight of Foetuses}

The observations on the changes of dimensions and weight of the developing foetuses were carried out from 10th day onwards. As can be seen from Table 1 both the crown-rump length and the weight are useful for the determination of the stage of pregnancy. However, in order to estimate the age of embryos on the basis of these parameters all foetuses from a given female should be measured to minimize error. This

Table 1

Increase in the size of foetuses between 10 and 18 days of pregnancy.

\begin{tabular}{|c|c|c|c|c|c|c|c|}
\hline \multirow{3}{*}{$\begin{array}{c}\begin{array}{c}\text { Day of } \\
\text { develop- } \\
\text { ment }\end{array} \\
10\end{array}$} & \multicolumn{4}{|c|}{ Body weight in $\mathrm{mg}$} & \multicolumn{3}{|c|}{ Crown-rump length in $\mathrm{mm}$} \\
\hline & $\begin{array}{l}\text { No. of } \\
\text { females }\end{array}$ & $\begin{array}{l}\text { No. of } \\
\text { foetuses }\end{array}$ & $\begin{array}{r}\text { Range } \\
\text { variatio }\end{array}$ & $\begin{array}{l}\text { of } \\
(\bar{x})\end{array}$ & $\begin{array}{l}\text { No. of } \\
\text { females }\end{array}$ & $\begin{array}{r}\text { No. of } \\
\text { foetuses }\end{array}$ & $\begin{array}{c}\text { Range of } \\
\text { variation }(\overline{\mathrm{x}})\end{array}$ \\
\hline & 1 & 3 & $8-14$ & (11) & 2 & 9 & $3.5-5 \quad(4.5)$ \\
\hline 11 & 3 & 10 & $26-66$ & $(41)$ & 2 & 8 & $6.5-8 \quad(7.0)$ \\
\hline 12 & 3 & 12 & $61-116$ & (91) & 1 & 5 & $9-10 \quad(9.5)$ \\
\hline 13 & 2 & 8 & $156-214$ & (192) & 1 & 3 & $10.5-11 \quad(11.0)$ \\
\hline 14 & 3 & 16 & $257-381$ & (323) & 2 & 10 & $12-13.5(12.5)$ \\
\hline 15 & 3 & 19 & $376-500$ & (437) & 2 & 12 & $14-15 \quad(14.5)$ \\
\hline 16 & 2 & 8 & $632-117$ & $(933)$ & 2 & 8 & $\begin{array}{lll}17 & -22 & (19.5)\end{array}$ \\
\hline 17 & 2 & 9 & $886-136$ & $(1056)$ & 2 & 9 & $16.5-22.5(20.0)$ \\
\hline 18 & 1 & 4 & $1805-182$ & $(1815)$ & 1 & 4 & $25-28 \quad(26.5)$ \\
\hline
\end{tabular}

methods is recommended for determination of age of foetuses 10 to 15-days old. In older foetuses this method is deceptive, similar to other morphological criteria.

\section{Morphology of Foetuses}

We begin the description of changes occurring in the external appearance of foetuses on 9th day of development. In the bank vole the phenomenon of reversal of germ layers occurs (O żd żeńs ki \& Mys tkow ska, 1976). In the initial perdiod of embryogenesis the body of the embryo is bent semicircularly with its dorsal surface to the inside. It is not until the 9th day that the embryo turns in effect assuming the shape characteristic of most mammalian embryos. At this stage the foetus can be easily excised from the uterus and separated from the foetal membranes. Particular foetuses may differ in the degree of development 
hence the establishment of the stage of pregnancy should be made after surveying several foetuses in a given female. The most characteristic features enabling establishment of the age of foetuses are listed in Table 2 .

$9 \mathrm{th}$ day (Plate V, Fig. 7). The majority of embryos have already turned and the following description applies only to these. The branchial arches are visible - large mandibular arch (often the incipient form of the maxillar process appears on it), hyoidal arch, and sometimes rudimentary arch III. The presumptive eye vesicle is still open to the diencephalon cavity, and at the level of hindbrain the auditory vesicle (often open) is visible. The posterior part of the neural tube may be still open. The heart is visible through the transparent abdominal wall. The forelimb buds are visible as small swellings. The 9-day old turned foetuses have 13 to 21 somites.

\section{Table 2}

Morphological features enabling estimation of the age of foetuses.

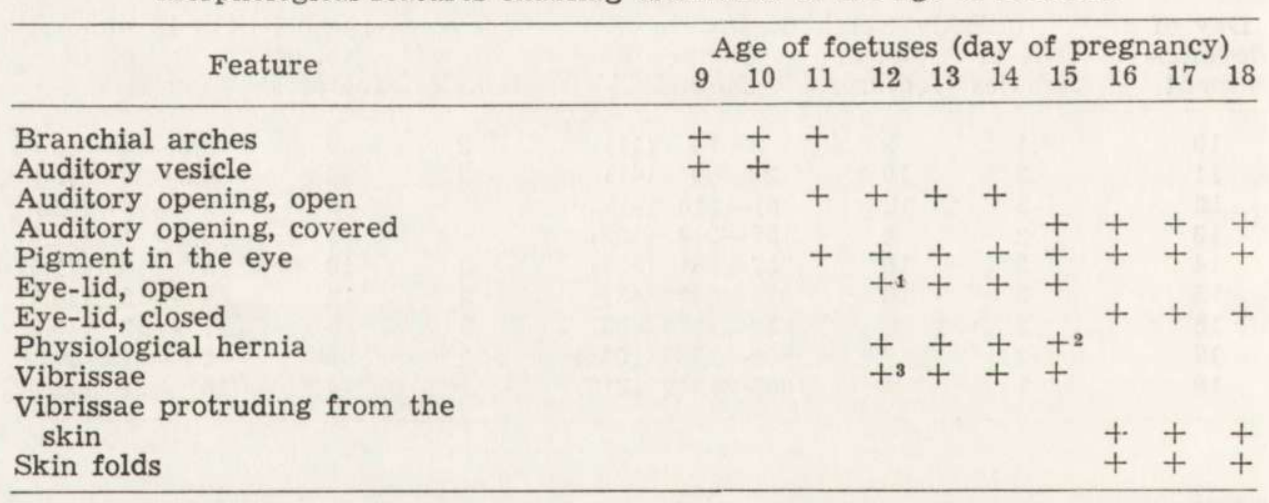

1 In some foetuses the eye-lid is not yet developed, 2 Some foetuses are without hernia, 8 Vibrissae are visible in some foetuses only.

$10 \mathrm{th}$ day (Plate V, Fig. 8). On this day all foetuses are turned. The two first branchial arches (mandibular and hyoid) are easily visible, the third one is slightly marked, the maxillar process appears on the mandibular arch. In some foetuses the lens is visible in the eye. The auditory vesicle is closed. The heart is visible through the transparent abdominal wall. The forelimb bud is in the form of a table-tennis bat, and the hindlimb bud forms a swelling on the side of the posterior part of the body. Segmentation is visible in the trunk and in the tail.

$1 \mathrm{ith} \mathrm{day} \mathrm{(Plate} \mathrm{V,} \mathrm{Fig.} \mathrm{9).} \mathrm{The} \mathrm{mouth} \mathrm{of} \mathrm{the} \mathrm{foetus} \mathrm{is} \mathrm{formed} \mathrm{but}$ maxillae are separated from the head. Pigment appears in the eye in the form of a circular band. The auditory opening is round, or in the form 
of vertical fissure. The heart is still visible through the abdominal wall. The forelimb buds are in the form of well shaped table-tennis bats and are separated from the trunk by a circular indentation. Hindlimb buds are of a similar shape, but only in some embryos they become separated from the trunk (Plate VI, Fig. 17). The segmentation is marked on the trunk and tail.

$12 \mathrm{th}$ day (Plate V, Fig. 10). The pigmented rim in the eye is very obvious. In some foetuses there appears a fine fold of the eyelid, not covering the eye-ball. In some embryos rudiments of vibrissae can be distinguished. Above the auditory opening a small pinna appears. Hands and feet, well separated from the trunk, assume pentagonal shape (especially hands) and show rudimentary digits (more distinct on the hand Plate VI, Fig. 18). Physiological hernia appears. Segmentation in the trunk and tail is still distinct.

$13 \mathrm{th}$ da y (Plate V, Fig. 11). The eye is heavily pigmented. In some embryos the eyelid fold partly covers the eye-ball. Rudiments of vibrissae are obvious. Above the auditory opening the rudiment of pinna protrudes. Both on the hand and foot the rudiments of digits are visible, partly separated by fissures (more distinct on the hand Plate VI, Fig. 19). The physiological hernia is distinct. Segmentation persists only in the caudal part of the body and in the tail. Hair follicles may by visible on the ventral side of the trunk.

$14 \mathrm{th}$ d a y (Plate V, Fig. 12). The eyelid partly covers the pigmented eye, and the pinna covers the auditory opening. The tongue is visible in the half-open mouth. The digits are well separated (on the foot of some animals only partly - Plate VI, Fig. 20). Rudiments of joints appear. Hair tollicles are barely visible but dispersed all over the body. The ribs show through the skin. Physiological hernia is very big. Segmentation persists in the tail only.

$15 \mathrm{th}$ day (Plate V, Fig. 13). The fissure between the eyelids is spindle-shaped. The pinna covers the auditory opening but does not accrete to the skin. All digits are separated. In the hand claws and callus start to form (Plate VI, Fig. 21). Hair follicles are visible on the whole body. Physiological hernia is present in some foetuses only.

$16 \mathrm{th}$ d a y (Plate V, Fig. 14). Vibrissae grow above the epithelium. The eye is completely covered by the eyelid. The pinna joins the skin below the auditory opening. In some foetuses pigment appears in the form of fine points scattered on the head and back. Secondary fusion of digits takes place. Claws and callus on the hand and foot are well developed (Plate VI, Fig. 22). Physiological hernia is absent. Foldings of skin transversal to the long axis of the trunk appear.

$17 \mathrm{th}$ day (Plate V, Fig. 15 and Plate VI, Fig. 23). The appearance 
of foetuses is similar to that of the previous day, but skin foldings are more distinct. Secondary fusion of digits is completed.

$18 \mathrm{th}$ d a y (Plate V, Fig. 16 and Plate VI, Fig. 24). In some females parturition occurs on this day, but in most cases it takes place on 19th day. The foetuses are considerably bigger and have more skin foldings than those one day younger (Table 1).

\section{CONCLUSIONS}

The changes in the female reproductive organs during pregnancy, as well as the changes in the size and appearance of foetuses, enable one to estimate the stage of pregnancy in the postimplantion period. The presence of the vaginal plug indicates that copulation occurred within the previous 12 hours or so. The presence of corpora lutea indicates only that ovulation took place and hence it is not a good criterion of pregnancy. The appearance of corpora lutea cannot be used to estimate the stage of pregnancy because they look similar during the whole pre- and postimplantation period, and moreover, they may persist for a few days even when implantation did not occur. In the case when corpora lutea are present but implantation swellings are not visible in the uterus, pregnancy can be detected only by discovering the embryos by flushing the reproductive tract or on histological sections.

In the evening of 5th day after copulation the implantation swellings appear in the uterus. Their shape permits the distinction of several periods of pregnancy: day 6, 7 to 12 and 13 to parturition. The accurate determination of the stage of pregnancy within these periods is possible only on the basis of the morphology and size of foetuses (weight and crown-rump length). These features allow accurate determination of the age of embryos in the period from 9th to 15th day. The accuracy of the estimation of the age of foetuses in the last three days of pregnancy $(16-18)$ is limited for two reasons. First, changes in the morphology of foetuses distinct up to 15th day of pregnancy become on later days elusive, being quantitative rather than qualitative in character. Second, considerable variability in the size of foetuses in the terminal period of pregnancy obliterates differences between foetuses of various age.

It should be remembered that in the females trapped in the field the pregnancy can be extended due to simultaneous lactation ( $\mathrm{B} \mathrm{ram}$ bell \& Row lands, 1936; T u pikova, 1964). In such a case the prolongation of pregnancy concerns only the preimplantation period and does not effect the duration of the postimplantation development. Hence, taking into account the appearance of uterus and foetuses it is possible to estimate fairly accurately the stage of pregnancy but such an estimation 
will provide information regarding the period of time up to parturition rather than the time that has elapsed from the moment of fertilization.

Acknowledgements: The authors express their gratitude to Professor A. K. T a r$\mathrm{k}$ owski for valuable suggestions and help provided in the course of the study, and to Professor Z. Pucek and Mrs. A. B u chalczyk, M. Sc., for rendering available the animals.

\section{REFERENCES}

1. Brambell F. W. R. \& Rowlands I. W., 1936: Reproduction of the Bank vole (Evotomys glareolus S chreber). Phil. Trans. R. Soc. B, 226: 71-97.

2. Buchalczyk A., 1970: Reproduction, mortality and longevity of the Bank vole under laboratory conditions. Acta theriol. 15, 10: 153-176.

3. Clarke J. R., Clulow F. V. \& Grieg F., 1970: Ovulation in the bank vole. J. Reprod. Fert. 23: 531.

4. Ożdżeński W. \& Mystkowska E. T., 1976: Implantation and early postimplantation development of the bank vole Clethrionomys glareolus ( $\mathrm{S} \mathrm{ch} \mathrm{r} \mathrm{e-}$ b e r). J. Embryol. exp. Morph., 35, 3.

5. Tupikova N. V., 1964: Izučenije razmnoženija i vozrastnogo sostava populacii mielkih mlekopitajuščih. [In: wMetody izučenija prirodnych očagov boleznej čeloveka «]. Medicina: 154-191, Moskva.

Accepted, Oct. 10, 1975.

Wacław OŻDŻEŃSKI i Ewa T. MYSTKOWSKA

\section{STADIA CIĄŻY U NORNICY RUDEJ}

\section{Streszczenie}

Przedstawiono sekwencje zmian zachodzących $w$ narządach płciowych $w$ trakcie ciąży oraz zmiany w ciężarze, długości i w morfologii zarodków nornicy rudej, Clethrionomys glareolus ( $\mathrm{Schreber}, 1780$ ) pomiędzy 9 dniem ciąży a porodem. Stwierdzono, że ciężar i długość ciemieniowo-pośladkowa jest dobrą cechą dla ustalenia stadium zaawansowania ciąży pomiędzy 10 a 15 dniem ciąży (Tabela 1). Ustalono pewne cechy morfologiczne, które pozwalają na określenie wieku zarodka pomiędzy 9 a 16 dniem rozwoju (Tabela 2, Tablice V i VI). 


\section{EXPLANATION OF PLATES}

\section{Plate IV}

The uteri of pregnant females in the postimplantation period (view from thee ventral side, objects magnified to similar size).

Fig. 1. 6th day, morning - site of implantation visible as small swelling (righit horn -1 implantation, left horn -2 implantation)

Figs. 2, 3, 4. Uteri in 7 th, 9 th and 12 th day of pregnancy. The implantatiom swellings are round in shape until the 12-13 day of pregnancy.

Figs. 5,6 . The uteri in 14 th and 15 th days of pregnancy.

The swellings are elongated and the embryos are visible through the uterine walll.

Placentae are distinctly visiblt.

\section{Plate V}

Foetuses 9 to 18 days old magnified to similar size; the real size is given im parentheses.

Fig. 7. 9-day-old foetus $(2 \mathrm{~mm})$.

Fig. 8. 10-day-old foetus $(4.5 \mathrm{~mm})$,

Fig. 9. 11-day-old foetus $(7 \mathrm{~mm})$.

Fig. 10. 12-day-old foetus $(9.5 \mathrm{~mm})$.

Fig. 11. 13-day-old foetus $(11 \mathrm{~mm})$.

Fig. 12. 14-day-old foetus $(12.5 \mathrm{~mm})$.

Fig. 13. 15-day-old foetus (14.5 $\mathrm{mm})$.

Fig. 14. 16-day-old foetus $(19.5 \mathrm{~mm})$.

Fig. 15. 17-day-old foetus $(20 \mathrm{~mm})$.

Fig. 16. 18-day-old foetus $(26.5 \mathrm{~mm})$.

\section{Plate VI}

Development of limbs. On the right side of each photograph - hand, on the lefft side - foot (objects reduced to similar size).

Fig. 17. 11th day - both limb buds are rounded up

Fig. 18. 12th day - the digits are visible

Fig. 19. 13th day - on the hand incisions between digits are distinct, on the foot - barely marked.

Fig. 20. 14th day - on the hand the digits are separated entirely, and on thie foot only partly.

Fig. 21. 15th day - on both the hand and the foot the digits are separated; thie elbow joint is distinctly marked.

Fig. 22. 16th day - the digits start to join together.

Fig. 23. 17th day - the digits are fused.

Fig. 24. 18th day - the picture similar to that on 17th day, but the arkle joinit is better marked. 

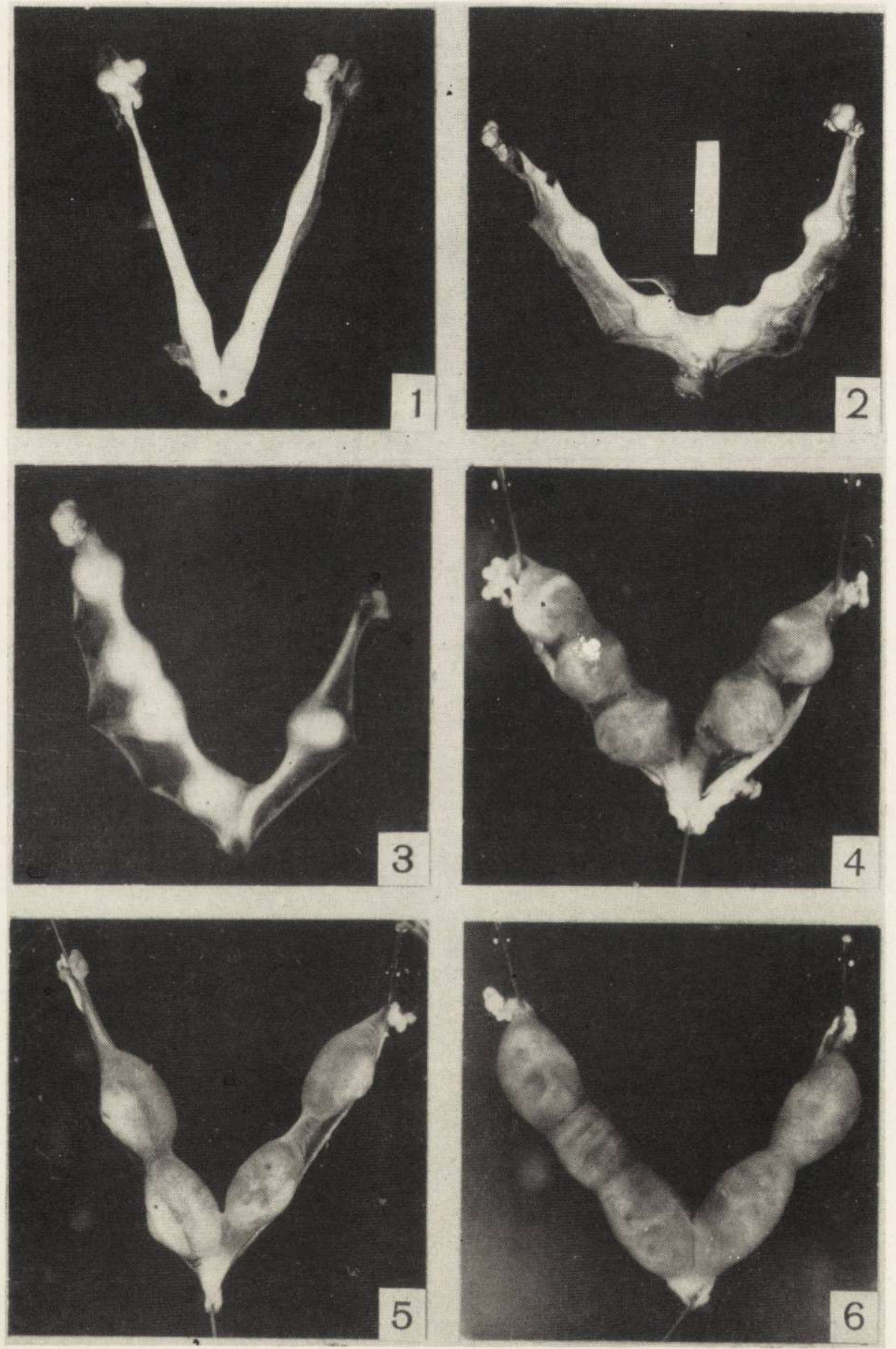

W. Ożdżeński \& E. T. Mystkowska 
ACTA THERIOLOGICA, Vol. XXI, 20.

Plate V.
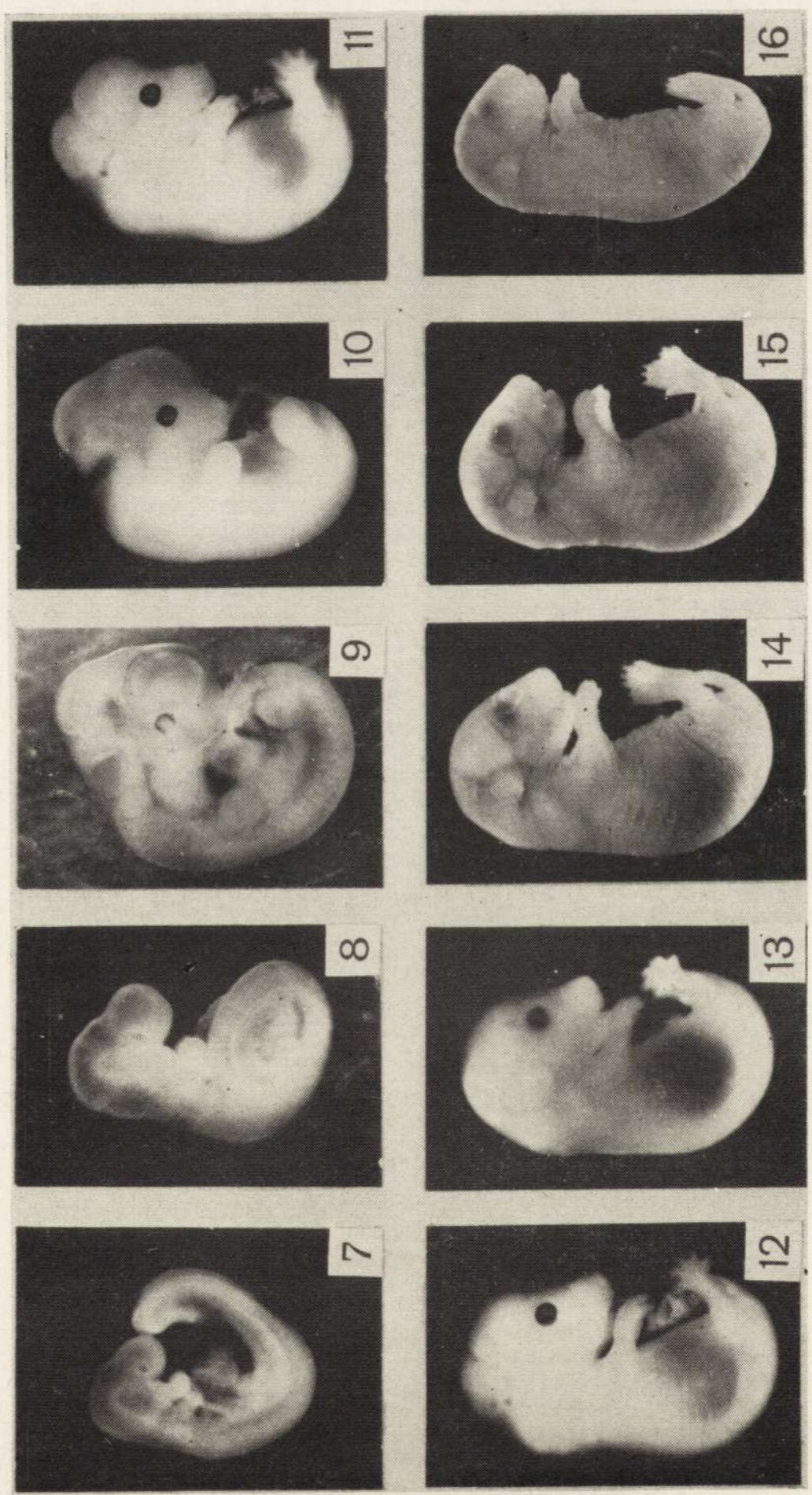

W. Ożdżeński \& E. T. Mystkowska 

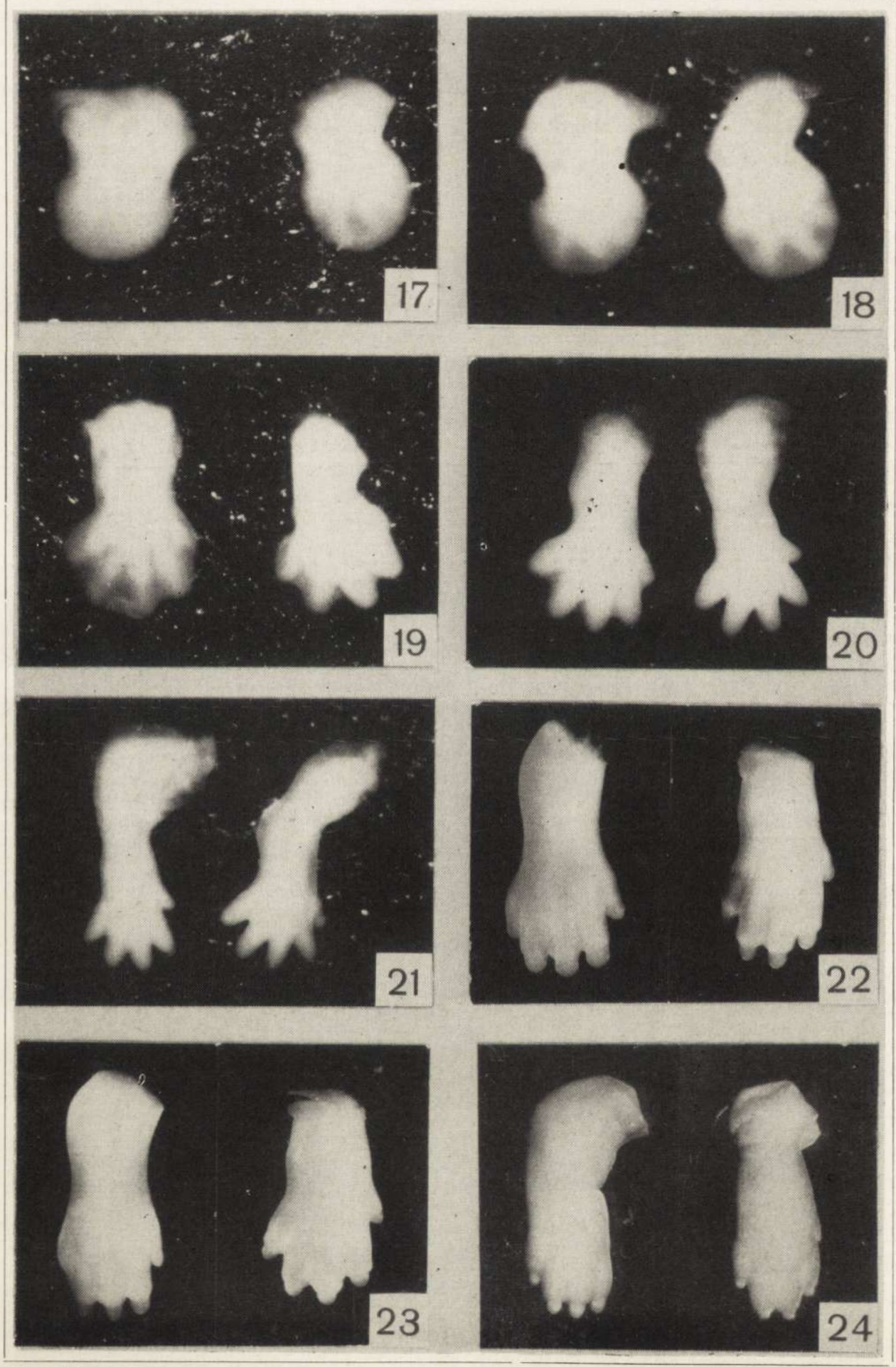

W. Ożdżeński \& E. T. Mystkowska auctores phot. 